\title{
Root Resorption Associated with Rapid Molar Intruder (RMI)
}

\author{
Omar Y. Mostafa, Amr R. El-Beialy, Mohamed A. Bushnak, \\ Omar Y. Moatafa: Master Degree (Orthodontics) - Cairo University \\ Amr R. El-Beialy: Lecturer Of Orthodontics - Cairo University \\ Mohamed A. Bushnak: Professor Of Orthodontics - Cairo University
}

\begin{abstract}
Introduction: Treatment of anterior open bite is based upon either intrusion of posterior teeth or extrusion of anterior teeth.Intrusion of posterior teeth might carry the risk of External root resorption (ERR). ERR is one of the worst and least predictable side effects of the orthodontic tooth movement. Currently, cone beam computed tomography $(C B C T)$ is considered the most accurate tool to evaluate the extent of ERR without extraction of the teeth.

Aim of the study: is to evaluate the effect of molar intrusion on the extent of external root resorption using CBCT.

Material and methods:Fifteen growing patients suffering from anterior open bite were treated by molar intrusion using rapid molar intruder (RMI) attached to a trans-palatal and lingual arches. CBCT was taken before treatment and after 6 months of active treatment.The length of the roots were compared prior to and after intrusion and statistically analyzed usingdescriptive tests and samples t test to evaluate the extent of ERR.

Results: the mean amount of root resorption was less than $1 \mathrm{~mm}$ and was considered clinically insignificant. Conclusion:The root resorption following molar intrusion using RMI in growing patients was not significant statistically and clinically.
\end{abstract}

Keywords: Molar intrusion, root resorption, open bite, rapid molar intruder, RMI

\section{Introduction}

Thetreatment philosophyof anterior open bite is based upon either intrusion of posterior teeth or extrusion of anterior teeth. The extrusion of anterior teeth should be avoided or minimized in cases with gummy smile, excessive incisal show. Intrusion of molars would be the most suitable and stable treatment for anterior open bite especially in cases with adequate incisal show, increased lower facial height and incompetent lips.

Molar intrusion can be done using different techniques and a multitude of appliances.High-pull headgear ${ }^{1}$, functional appliances ${ }^{2}$, bite blocks, vertical-pull chin cups ${ }^{3}$, spring loaded bite planes, repelling magnets ${ }^{45}$ and rapid molar intruder $(\mathrm{RMI})^{6,7,8}$ were advocated for treatment of anterior open bite by molar intrusion. Miniplates and miniscrews ${ }^{9,10,11,12}$ have been reported to be effective for molar intrusion and to limit any increases in the vertical dimension.External root resorption (ERR) is one of the undersirable and unpredictable side effects of orthodontic tooth movement. ${ }^{13}$ Among the various orthodontic tooth movements, intrusion is the most blamed for causing external root resorption. ${ }^{14}$ The difficulty to assess the ERR has been simplified by the current cone beam computed tomography (CBCT). It is considered the most accurate tool to evaluate the extent of ERR without extraction of the teeth. ${ }^{13,15,16,17}$ Therefor the aim of this study is to evaluate the extent of external root resorption associated with molar intrusionusing CBCT.

\section{Material And Methods}

Trial Design: A prospective clinical trial

Study setting and location: The study was carried out in the out-patient clinic of the Department of Orthodontics and Dentofacial Orthopedics, Faculty of Dentistry, Cairo University.

\section{Eligibility criteria}

1. Mild to moderate anterior open bite $(1-5 \mathrm{~mm})$

2. Need molar intrusion

3. No Previous orthodontic treatment

4..No syndromes or congenital defects

\section{Informed consent:}

Each patient's parent or guardian has to sign an informed consent contain the title, the aim, the steps, and the expected side effects of the study. 
Sample Size: 15 patients, with a resultant of 60 molars to be intruded Participants Time Line

Immediately after the protocol was accepted by the ethics committee, subjects selection started. Fifteen patient was selected and an informed consent was signed by each patient to approve the participation in the experiment. Molar intrusion was done using Rapid molar intruder (RMI) appliance joined to trans-palatal and lingual arches.(Fig. 1) CBCT was taken for each patient before the start of treatment and after 6 months of active treatment. A cone beam computed tomography was performed on the maxilla and mandible, under the following parameters: Resolution (Voxel size): $0.310 .3 \mathrm{~mm}$, exposure time: $7 \mathrm{sec}$, anode voltage: $120 \mathrm{kV}$, Anode current: $5 \mathrm{~mA}$ and Sensor: CCD-detector. The DICOM files obtained from the radiology center were opened using software Invivo 5 (Fig. 2) upon which the landmarks were identified, references were done and measurements were detected.

First, the landmarks were fed in the landmarks module, then the reference lines and planes used were constructed in the reference module, then the measurements were recorded in the measurement module. All the landmarks, references and measurement were recorded as special analysis on the software to be used to all the CBCT images of all the subjects. The landmarks were located on the 3D volume and refining was done on the generated multi-planar slice locator in the 3 cuts (axial, sagittal and coronal). The length of each root of the first permanent molar was measured before and after6 months of active intrusion. This generated 90 maxillary, 60 mandibular roots lengths respectively for the 30 upper and 30 lower molars in the 15 patients sample. The change in root length was calculated and statistically analyzed

\section{Statistical methods:}

Measure data were collected, analyzed and compared. Descriptive tests and comparing pre and post results were done using the paired sample $t$ tests.. Confidence level $(95 \%)$ and $p$-value $(0.5)$. The inter and intraobserver reliability were tested and analyzed

\section{Declaration of Interest}

The authors have no interest in any materials used in this research

\section{Results}

The average intrusion of the upper molars was $1 \mathrm{~mm}$ and the lower molars was $.82 \mathrm{~mm}$. The mean amount of change in the root length was less than $1 \mathrm{~mm}$ and the difference at the length of the roots was not significant except for the upper right molar mesiobuccal root and upper left molar distobuccal root. But still it was less than $1 \mathrm{~mm}$ (table 1,2)

\section{Generalizability}

The results of the inter-observer and intra-observer reliability tests show acceptable reliability for all the measures.

\section{Discussion}

Treatment of anterior open bite is based upon either intrusion of posterior teeth or extrusion of anterior teeth. In cases with adequate incisal show, increased lower facial height and incompetent lips, Molar intrusion would be the suitable treatment. Intrusion is the most orthodontic tooth movement blamed for causing external root resorption. CBCT is considered the most accurate tool to evaluate the extent of ERR without extraction of the teeth.Therefor The aim of this study is to evaluate the extent of external root resorption associated with molar intrusion using CBCT.

Molar intrusion was done using RMI to achieve a continuous light force for both upper and lower molars with no fixed appliance on the other teeth to avoid the effect of co-factors. RMI appliance joined to trans-palatal and lingual arches to avoid and buccal tipping of the molars. A cone beam computed tomography was performed on the maxilla and mandible, under the following parameters: Resolution (Voxel size): $0.3 \backslash 0.3$ mm, exposure time:7 sec, anode voltage: $120 \mathrm{kV}$, Anode current: $5 \mathrm{~mA}$ and Sensor: CCD-detector. The DICOM files obtained from the radiology center were opened using software Invivo 5 upon which the landmarks were identified, references were done and measurements were detected.

Two separate observers (O.Y. and M.A.) did the measures, also the first observer done the measurements twice at different situations. The results of the inter-observer and intra-observer reliability tests show acceptable reliability for all the measures. Thus confirm the reliability of the CBCT and the software used. Total of 150 roots (90 maxillary and 60 mandibular) were measured before and after the intrusion. The change in root length was calculated and statistically analyzedMean amount of change in the root length was less than $1 \mathrm{~mm}$ and the 
difference at the length of the roots was not significant except for the upper right molar mesiobuccal root and upper left molar distobuccal root. But still it was less than $1 \mathrm{~mm}$

Heravi etal, ${ }^{14}$ used the miniscrews for the upper molar intrusion and also measure the length of the roots prior and after the intrusion, they found that Mean root resorption of $0.3 \pm 0.2 \mathrm{~mm}$ for palatal root and $0.4 \mathrm{~mm}$ for mesiobuccal and distobuccal root was measured. And they considered these root resorption minor and clinically insignificant. These results were similar to the results of our study, the root resorption was more in the buccal roots than the palatal and was less than $1 \mathrm{~mm}$ for all the roots which is clinically insignificant.

\section{Conclusion}

The root resorption following molar intrusion using rapid molar intruder (RMI) in growing patients was not statistically nor clinically significant.

\section{Refrences}

[1]. Dellinger EL. A clinical assessment of the Active Vertical Corrector--a nonsurgical alternative for skeletal open bite treatment. Am J Orthod. 1986;89(5):428-436. http://www.ncbi.nlm.nih.gov/pubmed/3458375. Accessed May 17, 2016.

[2]. Defraia E, Marinelli A, Baroni G, Franchi L, Baccetti T. Early orthodontic treatment of skeletal open-bite malocclusion with the open-bite bionator: a cephalometric study. Am J Orthod Dentofacial Orthop. 2007;132(5):595-598. doi:10.1016/j.ajodo.2005.12.035

[3]. Schulz SO, McNamara JA, Baccetti T, Franchi L. Treatment effects of bonded RME and vertical-pull chincup followed by fixed appliance in patients with increased vertical dimension. Am J Orthod Dentofacial Orthop. 2005;128(3):326-336. doi:10.1016/j.ajodo.2004.03.039.

[4]. Kalra V, Burstone CJ, Nanda R. Effects of a fixed magnetic appliance on the dentofacial complex. Am J Orthod Dentofacial Orthop. 1989;95(6):467-478. http://www.ncbi.nlm.nih.gov/pubmed/2729196. Accessed May 17, 2016.

[5]. Kiliaridis S, Egermark I, Thilander B. Anterior open bite treatment with magnets. Eur J Orthod. 1990;12(4):447-457. http://www.ncbi.nlm.nih.gov/pubmed/2086265. Accessed October 23, 2015.

[6]. Carano A, Siciliani G, Bowman SJ. Treatment of skeletal open bite with a device for rapid molar intrusion: A preliminary report. Angle Orthod. 2005;75(5):736-746. doi:10.1043/0003-3219(2005)75[736:TOSOBW]2.0.CO;2.

[7]. Cinsar A, Alagha AR, Akyalçin S. Skeletal open bite correction with rapid molar intruder appliance in growing individuals. Angle Orthod. 2007;77(4):632-639. doi:10.2319/071406-292.

[8]. Albogha MH, Takahashi I, Sawan MN. Early treatment of anterior open bite: Comparison of the vertical and horizontal morphological changes induced by magnetic bite-blocks and adjusted rapid molar intruders. Korean J Orthod. 2015;45(1):38-46. doi:10.4041/kjod.2015.45.1.38

[9]. Sherwood KH, Burch JG, Thompson WJ. Closing anterior open bites by intruding molars with titanium miniplate anchorage. Am J Orthod Dentofacial Orthop. 2002;122(6):593-600. doi:10.1067/mod.2002.128641.

[10]. Moon C-H, Wee J-U, Lee H-S. Intrusion of overerupted molars by corticotomy and orthodontic skeletal anchorage. Angle Orthod. 2007;77(6):1119-1125. doi:10.2319/092705-334.1.

[11]. Marzouk ES, Abdallah EM, El-Kenany WA. Molar Intrusion in Open-bite Adults Using Zygomatic Miniplates. Int J Orthod Milwaukee. 2015;26(2):47-54. http://www.ncbi.nlm.nih.gov/pubmed/26349291. Accessed May 17, 2016.

[12]. Kook YA, Park JH, Kim Y, Ahn CS, Bayome M. Orthodontic Treatment of Skeletal Class II Adolescent with Anterior Open Bite using Mini-Screws and Modified Palatal Anchorage Plate. J Clin Pediatr Dent. 2015;39(2):187-192. http://www.ncbi.nlm.nih.gov/pubmed/25823491. Accessed May 17, 2016.

[13]. Topkara A, Karaman AI, Kau CH. Apical root resorption caused by orthodontic forces: A brief review and a long-term observation. $\begin{array}{llll}\text { Eur J } & \text { Dent. 2012;6(4):445-453. }\end{array}$ http://www.pubmedcentral.nih.gov/articlerender.fcgi?artid=3474562\&tool=pmcentrez\&rendertype=abstract. Accessed May 17, 2016.

[14]. Heravi F, Bayani S, Madani AS, Radvar M, Anbiaee N. Intrusion of supra-erupted molars using miniscrews: clinical success and root resorption. Am J Orthod Dentofacial Orthop. 2011;139(4 Suppl):S170-S175. doi:10.1016/j.ajodo.2009.06.032.

[15]. Shokri A, Mortazavi H, Salemi F, Javadian A, Bakhtiari H, Matlabi H. Diagnosis of simulated external root resorption using conventional intraoral film radiography, CCD, PSP, and CBCT: a comparison study. Biomed J. 36(1):18-22. doi:10.4103/23194170.107156

[16]. Schwartz JP, Raveli TB, Almeida KC de M, Schwartz-Filho HO, Raveli DB. Cone beam computed tomography study of apical root resorption induced by Herbst appliance. J Appl Oral Sci. 2015;23(5):479-485. doi:10.1590/1678-775720150224.

[17]. Lima TFR, Gamba T de O, Zaia AA, Soares A de J. Evaluation of cone beam computed tomography and periapical radiography in the diagnosis of root resorption. Aust Dent J. January 2016. doi:10.1111/adj.12407.

Figure 1 RMI appliance attached to TPA and lingual arch

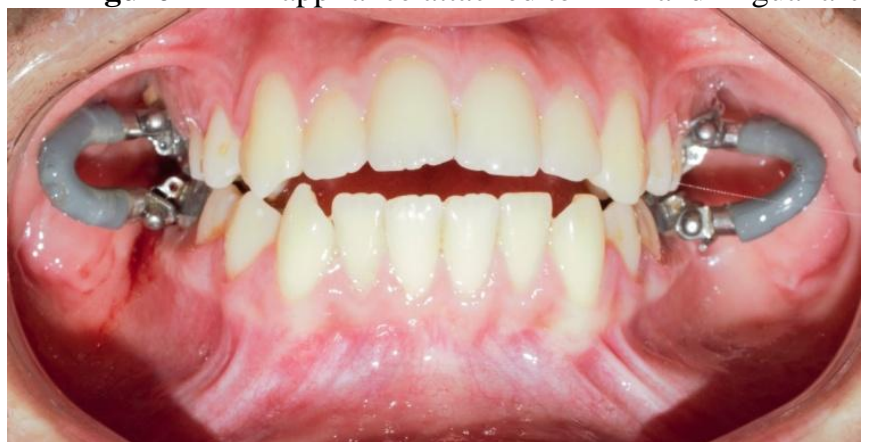



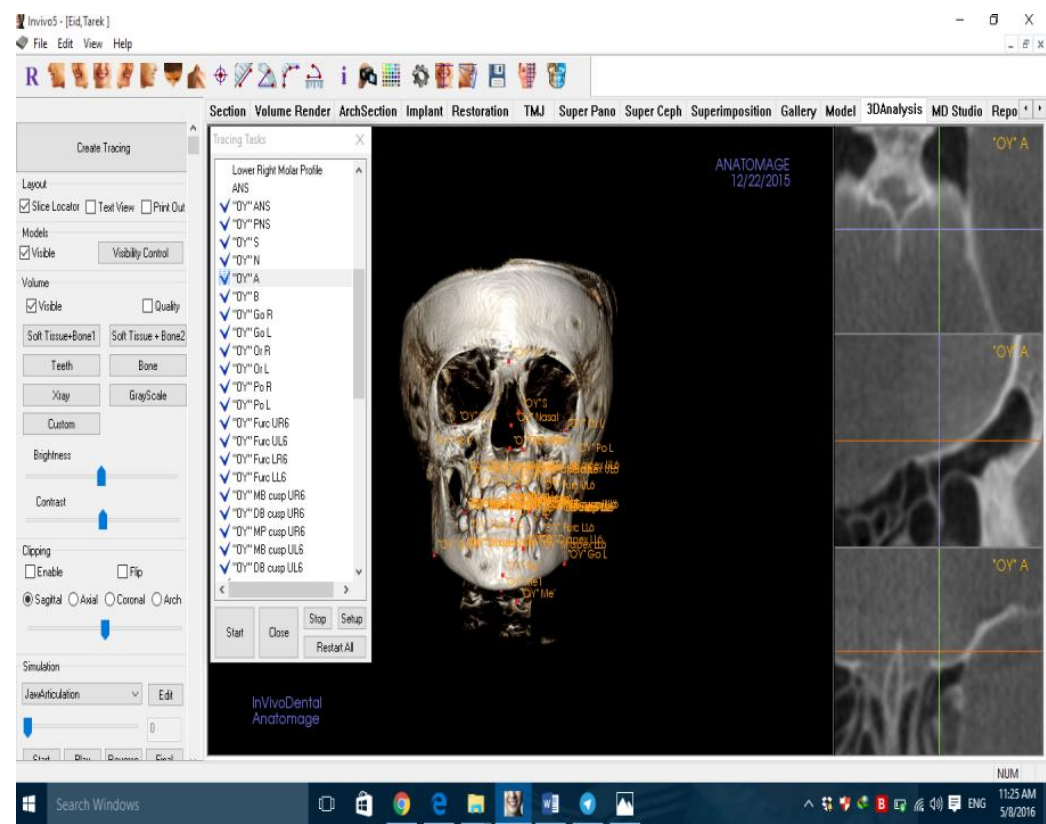

Figure 2 the landmarks located at the In-vivo Anatomage soft-ware using 3D volume and refined on the 3 dimensions slice locator.

Results: Results of descriptive tests for the treatment group

\begin{tabular}{|c|c|c|c|}
\hline Measurement & & $\mathrm{N}$ & Mean \\
\hline \multirow{3}{*}{ UR6 MB } & Pre & 15 & 18.35 \\
\hline & Post & 15 & 17.94 \\
\hline & Difference & 15 & -0.41 \\
\hline \multirow{3}{*}{ UR6 DB } & Pre & 15 & 18.20 \\
\hline & Post & 15 & 17.63 \\
\hline & Difference & 15 & -0.57 \\
\hline \multirow{3}{*}{ UR6 P } & Pre & 15 & 19.89 \\
\hline & Post & 15 & 19.58 \\
\hline & Difference & 15 & -0.32 \\
\hline \multirow{3}{*}{ UL6 MB } & Pre & 15 & 18.58 \\
\hline & Post & 15 & 18.05 \\
\hline & Difference & 15 & -0.53 \\
\hline \multirow{3}{*}{ UL6 DB } & Pre & 15 & 18.33 \\
\hline & Post & 15 & 18.21 \\
\hline & Difference & 15 & -0.21 \\
\hline \multirow{3}{*}{ UL6 P } & Pre & 15 & 19.85 \\
\hline & Post & 15 & 19.98 \\
\hline & Difference & 15 & 0.13 \\
\hline \multirow{3}{*}{ LR6 M } & Pre & 15 & 19.48 \\
\hline & Post & 15 & 19.44 \\
\hline & Difference & 15 & -0.04 \\
\hline \multirow{3}{*}{ LR6 D } & Pre & 15 & 19.14 \\
\hline & Post & 15 & 19.19 \\
\hline & Difference & 15 & 0.04 \\
\hline \multirow{3}{*}{ LL6 M } & Pre & 15 & 19.48 \\
\hline & Post & 15 & 19.16 \\
\hline & Difference & 15 & -0.32 \\
\hline \multirow{3}{*}{ LL 6 D } & Pre & 15 & 18.90 \\
\hline & Post & 15 & 18.74 \\
\hline & Difference & 15 & -0.15 \\
\hline
\end{tabular}

Results of Paired samples t Test for comparing PRE -POST of each variable

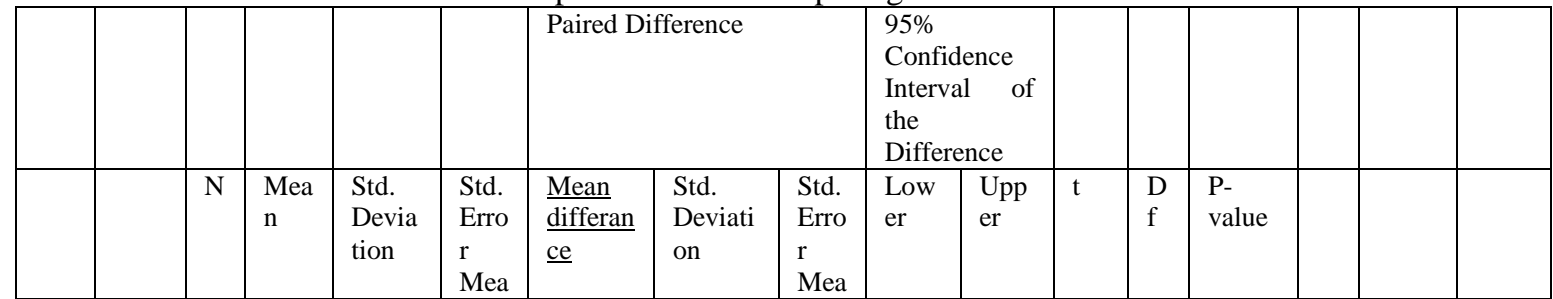


Root Resorption Associated With Rapid Molar Intruder (RMI)

\begin{tabular}{|c|c|c|c|c|c|c|c|c|c|c|c|c|c|c|}
\hline & & & & & $\mathrm{n}$ & & & $\mathrm{n}$ & & & & & & \\
\hline \multirow{2}{*}{$\begin{array}{l}\frac{\mathrm{UR}}{6} \\
\underline{\mathrm{M}} \\
\underline{\mathrm{B}}\end{array}$} & PRE & $\begin{array}{l}1 \\
5\end{array}$ & $\begin{array}{l}18.3 \\
5\end{array}$ & 1.46 & 0.38 & \multirow[t]{2}{*}{$\underline{-0.41}$} & \multirow[t]{2}{*}{1.10} & \multirow[t]{2}{*}{0.28} & \multirow[t]{2}{*}{$\begin{array}{l}- \\
1.02\end{array}$} & \multirow[t]{2}{*}{0.19} & \multirow{2}{*}{$\begin{array}{l}- \\
1.4 \\
6\end{array}$} & \multirow[t]{2}{*}{$\begin{array}{l}1 \\
4\end{array}$} & \multirow[t]{2}{*}{$\begin{array}{l}0.166 \\
69\end{array}$} & \multirow[t]{2}{*}{$\begin{array}{l}\mathrm{P}>0.05 \text { Non- } \\
\underline{\text { Significant }}\end{array}$} \\
\hline & $\begin{array}{l}\text { POS } \\
\text { T }\end{array}$ & $\begin{array}{l}1 \\
5\end{array}$ & $\begin{array}{l}17.9 \\
4\end{array}$ & 1.92 & 0.5 & & & & & & & & & \\
\hline \multirow{2}{*}{$\begin{array}{l}\underline{\mathrm{UR}} \\
\underline{6} \\
\mathrm{DB}\end{array}$} & PRE & $\begin{array}{l}1 \\
5\end{array}$ & $\begin{array}{l}18.2 \\
0\end{array}$ & 1.57 & 0.41 & \multirow[t]{2}{*}{-0.57} & \multirow[t]{2}{*}{0.98} & \multirow[t]{2}{*}{0.25} & \multirow[t]{2}{*}{$-\overline{1.12}$} & \multirow[t]{2}{*}{$\overline{-} .03$} & \multirow{2}{*}{$\begin{array}{l}- \\
2.2 \\
5\end{array}$} & \multirow[t]{2}{*}{$\begin{array}{l}1 \\
4\end{array}$} & \multirow[t]{2}{*}{$\begin{array}{l}0.041 \\
25\end{array}$} & \multirow[t]{2}{*}{$\begin{array}{l}\mathrm{P} \quad< \\
\underline{\text { Significant }}\end{array}$} \\
\hline & $\begin{array}{l}\text { POS } \\
\text { T }\end{array}$ & $\begin{array}{l}1 \\
5\end{array}$ & $\begin{array}{l}17.6 \\
3\end{array}$ & 1.69 & 0.44 & & & & & & & & & \\
\hline \multirow[t]{2}{*}{$\underline{\mathrm{UR}}$} & PRE & $\begin{array}{l}1 \\
5\end{array}$ & $\begin{array}{l}19.8 \\
9\end{array}$ & 1.25 & 0.32 & \multirow[t]{2}{*}{$\underline{-0.32}$} & \multirow[t]{2}{*}{0.76} & \multirow[t]{2}{*}{0.20} & \multirow[t]{2}{*}{$\begin{array}{l}-74 \\
0.74\end{array}$} & \multirow[t]{2}{*}{0.10} & \multirow{2}{*}{$\begin{array}{l}- \\
1.6 \\
1\end{array}$} & \multirow[t]{2}{*}{$\begin{array}{l}1 \\
4\end{array}$} & \multirow[t]{2}{*}{$\begin{array}{l}0.128 \\
91\end{array}$} & \multirow[t]{2}{*}{$\begin{array}{lrl}\mathrm{P}>0.05 & \text { Non- } \\
\underline{\text { Significant }} & \end{array}$} \\
\hline & $\begin{array}{l}\text { POS } \\
\text { T }\end{array}$ & $\begin{array}{l}1 \\
5\end{array}$ & $\begin{array}{l}19.5 \\
8\end{array}$ & 1.51 & 0.39 & & & & & & & & & \\
\hline \multirow{2}{*}{$\begin{array}{l}\frac{\mathrm{UL}}{\underline{6}} \\
\underline{\mathrm{M}} \\
\underline{\mathrm{B}}\end{array}$} & PRE & $\begin{array}{l}1 \\
5\end{array}$ & $\begin{array}{l}18.5 \\
8\end{array}$ & 1.39 & 0.36 & $\underline{-0.53}$ & 1.11 & 0.29 & $\overline{-}-1.15$ & 0.08 & $\begin{array}{l}- \\
1.8\end{array}$ & $\begin{array}{l}1 \\
4\end{array}$ & $\begin{array}{l}0.083 \\
71\end{array}$ & $\begin{array}{l}\mathrm{P} \approx 0.05 \text { Almost } \\
\underline{\text { Significant }}\end{array}$ \\
\hline & $\begin{array}{l}\text { POS } \\
\text { T }\end{array}$ & $\begin{array}{l}1 \\
5\end{array}$ & $\begin{array}{l}18.0 \\
5\end{array}$ & 1.23 & 0.32 & & & & & & 6 & & & \\
\hline$\frac{\mathrm{UL}}{\underline{6}}$ & PRE & $\begin{array}{l}1 \\
5\end{array}$ & $\begin{array}{l}18.3 \\
3\end{array}$ & 1.31 & 0.34 & -0.12 & 1.05 & 0.27 & $\overline{-}-70$ & 0.46 & $\begin{array}{l}- \\
0.4\end{array}$ & $\begin{array}{l}1 \\
4\end{array}$ & $\begin{array}{l}0.659 \\
88\end{array}$ & $\begin{array}{lll}\mathrm{P}>0.05 & \text { Non- } \\
\text { Significant }\end{array}$ \\
\hline DB & $\begin{array}{l}\text { POS } \\
\mathrm{T}\end{array}$ & $\begin{array}{l}1 \\
5\end{array}$ & $\begin{array}{l}18.2 \\
1 \\
\end{array}$ & 1.81 & 0.47 & & & & & & 5 & & & \\
\hline$\frac{\mathrm{UL}}{6 \mathrm{P}}$ & PRE & $\begin{array}{l}1 \\
5\end{array}$ & $\begin{array}{l}19.8 \\
5\end{array}$ & 1.37 & 0.35 & $\underline{0.13}$ & 0.82 & 0.21 & $\overline{-}-33$ & 0.58 & $\begin{array}{l}0.6 \\
1\end{array}$ & $\begin{array}{l}1 \\
4\end{array}$ & $\begin{array}{l}0.553 \\
73\end{array}$ & $\begin{array}{l}\mathrm{P}>0.05 \text { Non- } \\
\text { Significant }\end{array}$ \\
\hline & $\begin{array}{l}\text { POS } \\
\mathrm{T}\end{array}$ & $\begin{array}{l}1 \\
5\end{array}$ & $\begin{array}{l}19.9 \\
8\end{array}$ & 1.7 & 0.44 & & & & & & & & & \\
\hline$\frac{\mathrm{LR}}{6}$ & PRE & $\begin{array}{l}1 \\
5\end{array}$ & $\begin{array}{l}19.4 \\
8\end{array}$ & 1.51 & 0.39 & -0.04 & 0.96 & 0.25 & $\overline{-} .57$ & 0.49 & $\begin{array}{l}- \\
0.1\end{array}$ & $\begin{array}{l}1 \\
4\end{array}$ & $\begin{array}{l}0.886 \\
40\end{array}$ & $\begin{array}{lll}\mathrm{P}>0.05 & \text { Non- } \\
\text { Significant }\end{array}$ \\
\hline$\underline{\underline{M}}$ & $\begin{array}{l}\text { POS } \\
\mathrm{T}\end{array}$ & $\begin{array}{l}1 \\
5 \\
\end{array}$ & $\begin{array}{l}19.4 \\
4 \\
\end{array}$ & 1.56 & 0.4 & & & & & & 5 & & & \\
\hline$\frac{L R}{6 D}$ & PRE & $\begin{array}{l}1 \\
5\end{array}$ & $\begin{array}{l}19.1 \\
4\end{array}$ & 1.28 & 0.33 & 0.04 & 0.79 & 0.20 & $\begin{array}{l}- \\
0.39\end{array}$ & 0.48 & $\begin{array}{l}0.2 \\
1\end{array}$ & $\begin{array}{l}1 \\
4\end{array}$ & $\begin{array}{l}0.837 \\
13\end{array}$ & $\begin{array}{l}\mathrm{P}>0.05 \text { Non- } \\
\text { Significant }\end{array}$ \\
\hline & $\begin{array}{l}\text { POS } \\
\mathrm{T} \\
\end{array}$ & $\begin{array}{l}1 \\
5\end{array}$ & $\begin{array}{l}19.1 \\
9\end{array}$ & 1.51 & 0.39 & & & & & & & & & \\
\hline$\frac{\mathrm{LL}}{6}$ & PRE & $\begin{array}{l}1 \\
5\end{array}$ & $\begin{array}{l}19.4 \\
8\end{array}$ & 1.55 & 0.40 & -0.32 & 0.97 & 0.25 & $\overline{-}$ & 0.21 & $\begin{array}{l}- \\
1.2\end{array}$ & $\begin{array}{l}1 \\
4\end{array}$ & $\begin{array}{l}0.218 \\
72\end{array}$ & $\begin{array}{l}\mathrm{P}>0.05 \text { Non- } \\
\text { Significant }\end{array}$ \\
\hline$\underline{\mathrm{M}}$ & $\begin{array}{l}\text { POS } \\
\mathrm{T}\end{array}$ & $\begin{array}{l}1 \\
5 \\
\end{array}$ & $\begin{array}{l}19.1 \\
6 \\
\end{array}$ & 1.81 & 0.47 & & & & & & 9 & & & \\
\hline$\frac{\mathrm{LL}}{6 \mathrm{D}}$ & PRE & $\begin{array}{l}1 \\
5 \\
\end{array}$ & $\begin{array}{l}18.9 \\
0 \\
\end{array}$ & 1.22 & 0.32 & $\underline{-0.15}$ & 1.20 & 0.31 & $\overline{-}$ & 0.51 & $\begin{array}{l}- \\
0.4\end{array}$ & $\begin{array}{l}1 \\
4\end{array}$ & $\begin{array}{l}0.631 \\
48\end{array}$ & \\
\hline & $\begin{array}{l}\text { POS } \\
\text { T }\end{array}$ & $\begin{array}{l}1 \\
5\end{array}$ & $\begin{array}{l}18.7 \\
4\end{array}$ & 1.84 & 0.47 & & & & & & 9 & & & $\begin{array}{ll}\mathrm{P} \quad>\quad 0.05 \\
\text { Non- } \\
\text { Significant }\end{array}$ \\
\hline
\end{tabular}

